\title{
The determinants of cooperation in buyer- supplier relationships: evidence from certified companies ${ }^{5}$
}

\author{
Article history: \\ Received: 16 January 2018 \\ Sent for revision: 1 February 2018 \\ Received in revised form: 16 March 2018 \\ Accepted: 18 March 2018 \\ Available online: 20 March 2018
}

\begin{abstract}
The aim of this study is to propose and empirically examine an integrated model of the development of cooperation in buyer-seller relationships. Building upon previous research a conceptual framework of the relationships between communication, trust, satisfaction with the relationship and relationship commitment and their impact on cooperation has been proposed and empirically examined from the perspective of certified buyers. The application of structural equation modelling on a sample of 186 certified companies operating on Serbian market indicated the antecedent role of communication to trust and the direct influence of trust and commitment on the development of cooperation. Implications of this research are discussed and limitations and directions for future research are highlighted.
\end{abstract}

Keywords: communication, trust, satisfaction with the relationship, relationship commitment, cooperation in buyer-seller relationships

\footnotetext{
${ }^{1}$ University of Belgrade, Technical faculty in Bor, imilosevic@tfbor.bg.ac.rs

${ }^{2}$ University of Belgrade, Faculty of Organizational Sciences

${ }^{3}$ Economics Institute a.d. Belgrade

${ }^{4}$ University of Belgrade, Technical faculty in Bor

${ }^{5}$ This paper is the result of research project no. 179001 financed by the Ministry of Education, Science and Technological Development of the Republic of Serbia
} 
Milošević l. et. al.: The determinants of cooperation in buyer-supplier relationships...

\title{
Determinante saradnje u odnosima kupac-isporučilac: rezultati na uzorku sertifikovanih kompanija
}

\begin{abstract}
Apstrakt: Cilj ovog istraživanja je da predloži i empirijski ispita integrisani model razvoja saradnje u odnosima između kompanija i njihovih isporučilaca. Na osnovu prethodnih istraživanja predložen je konceptualni model kojim su obuhvaćeni odnosi između koncepata komunikacija, poverenje, satisfakcija odnosom i posvećenost razvoju odnosa i njihov uticaj na razvoj saradnje u odnosima kupac-isporučilac. Model je empirijski ispitan iz perspektive sertifikovanih kompanija u ulozi kupaca. Primenom modelovanja pomoću strukturnih jednačina na uzorku od 186 sertifikovanih kompanija koje pos/uju na tržištu Srbije utvrđeno je da komunikacija predstavlja direktnu determinantu poverenja $i$ da poverenje i posvećenost odnosu utiču na unapređenje saradnje $u$ odnosima kupac-isporučilac. $U$ radu su razmotrene implikacije koje proizilaze iz ovog istraživanja $i$ istaknuta su ograničenja $i$ smernice za buduća istraživanja.
\end{abstract}

Ključne reči: komunikacija, poverenje, satisfakcija odnosom, posvećenost odnosu, saradnja u odnosima kupac- isporučilac

\section{Introduction}

Rapidly changing business environments have forced companies to seek for new creative means of responding to competitive challenges. Realizing that competitive pressures increasingly stem from networks of companies, companies become aware of the necessity of establishing effective cooperation within networks in order to compete successfully. In these circumstances companies' attention is diverted from the establishment of onetime transactions with customers and suppliers towards establishing, maintaining and nurturing long-term relationships. Previous research indicates that collaborative relationships offer greater benefits. i.e. higher level of satisfaction and performance, in comparison with transactional relationships (Whipple et al., 2010). Trust and commitment are recognized as key prerequisites of successful relationship marketing (Morgan \& Hunt, 1994; Aurier \& N'Goala, 2010; Huang \& Wilkinson, 2013). Trust and commitment motivate companies to invest in relationships with exchange partners and resist short-term incentives in order to reap the benefits of long-term cooperation. Aurier and N'Goala (2010) put forward that trust enhances customer's level of service usage and cross-buying behaviour of the relationship, whereas relationship commitment positively affects relationship duration and diminishes customer's inclinations to establish multiple relationships with various suppliers. When difficulties arise and B2B relationships face dissolution, close relationship among the B2B stakeholders, 
Milošević I. et. al.: The determinants of cooperation in buyer-supplier relationships...

characterized by mutual trust and relationship commitment, promote the willingness of exchange partners to repair the dysfunctional relationship and continue cooperation (Fleming et al., 2016). Both of these constructs are relevant in conditions which imply uncertainty and vulnerability of an exchange partner, lack of adequate knowledge of a company of the services provided by the other party, lack of influence of a company over the exchange partner and in instances when the consequences of exchange partner's actions can significantly affect the outcomes of the other party (Moorman et al., 1993). Exchange of information among partners, which is relevant, accurate and timely, enhances channel outcomes and contributes to trust in the relationship and relationship commitment, which further strengthen partners' cooperation (Morgan \& Hunt, 1994; Mohr et al., 1996). Literature defines cooperation as joint efforts of companies in an interdependent relationship which are expected to bring about outcomes which surpass results that a company would achieve if it acted solely (Anderson \& Narus, 1990). In addition to trust and commitment, previous empirical research in the context of buyer-seller relationships has highlighted the relevance of relationship satisfaction for buyer's diffidence to search for alternative suppliers and inclination to invest maximum effort to maintain valued relationship (Barry et al., 2008).

Trust, satisfaction and relationship commitment have been the subject of much research attention (Palmatier et al., 2006; Whipple et al., 2010; Dowell et al., 2015; Akrout \& Diallo, 2017). These constructs are regarded as key dimensions of relationship quality (Barry et al., 2008; Rafiq et al., 2013) and relationship performance (Lages et al., 2008) and necessary prerequisites of long-term cooperation in B2B relationships. However, the antecedents of cooperation in buyer-supplier relationships among companies operating on Serbian market have mainly stayed an under-researched topic. As to the best of our knowledge, no previous study has examined the development and consequences of trust, relationship satisfaction and commitment from the perspective of certified companies operating in Serbia.

Standardization is a key part of the microeconomic infrastructure with the benefits arising from the reduction of costs and the growth of quality (Swann, 2000). Standardization process quickly became a global phenomenon in many industries, especially today in the context of e-markets creating incentive for cooperation between buyers and suppliers as a necessity for competitiveness. (Kauffman \& Tsai, 2010). Although standardization cannot raise profitability in all companies, still, it is in the interests of the economy as a whole, because it encourages competition (Trajković \& Milošević, 2018). According to Polo-Redondo and Cambra-Fierro (2008) certification of business processes is an indication of quality of a company's goods and services and contributes to customers' perceptions of the company as a reliable and trustworthy supplier. Certification of a management system is 
Milošević l. et. al.: The determinants of cooperation in buyer-supplier relationships...

regarded as an independent justification of conformity to standards, it does not automatically result in better financial performance of a company, however, if it is properly applied certification is expected to lead to improved business performance (Alic, 2014). Recent research provides empirical evidence of positive impact of ISO certification on customers' perceptions of product and service quality and its impact on brand image, which further contribute to customer purchase intentions (Wu \& Jang, 2013; Wu \& Jang, 2014). As conformity to the requirements for a quality management system leads to numerous marketing benefits, such as a decrease in customer complaints and an increase in customer satisfaction, acquisition of new and retention of existing customers, increase in sales volume, market share, easier entrance into new markets, improved brand image, etc. (RubioAndrada et al., 2011; Alic, 2014), certified companies prefer to establish longterm cooperation with suppliers that have implemented ISO quality management system (Polo-Redondo \& Cambra-Fierro, 2008). Recent findings from a hotel industry indicate that the implementation of a certified quality system by small and medium-sized enterprises positively affects company's relationships with stakeholders, wheras in the context of small enterpises the main beneficiaries of company's quality certification are its suppliers (RubioAndrada et al., 2011)

As the development of cooperation and its antecedents in B2B relationships among certified buyers and their suppliers in the context of Serbian market has been scarcely examined thus far, the aim of the present study is to fill this void in the literature.

\section{Literature review}

\subsection{Trust}

Trust is considered as one of the main constructs in business relationships and as such has been much studied (Moorman et al., 1993; Morgan \& Hunt, 1994; Palmatier et al., 2006; Akrout \& Diallo, 2017). It has been conceptualized as an an individual's expectation that the other party will adhere to its promises. The main facets of trust are an expectation, a promise and a capacity to rely on the behaviour of the other party. According to the most widely accepted conceptualization, trust is defined as a "willingness to rely on an exchange partner in whom one has confidence" (Moorman et al., 1993; p.82). This conceptualization implies trust as a belief in a trustworthiness of an exchange partner, which is based on the partner's reliability and expertise, and trust as a behavioural intention, i.e. reliance on fair behaviour of the exchange partner. 
Milošević I. et. al.: The determinants of cooperation in buyer-supplier relationships...

In addition to this unidimensional and static perspective, trust has also been conceptualized from the process and multistage perspective. Huang and Wilkinson (2013) make distinctions between cognitive and affective trust, whereas cognitive trust is based on rational expectations related to the behaviour of an exchange partner and likely outcomes of collaboration with the partner, whereas affective trust implies emotional bond and expectation of an exchange partner's caring for the welfare of the other party and the maintenance of a relationship. The existence of cognitive and affective trust is also supported by Dowell et al. (2015), who highlighted the importance of affective trust in early phases of relationship development and cognitive trust in the mature phase of relationship lifecycle. Recent research differentiates between calculative, affective, cognitive and behavioural trust, whereas calculative trust is based on a confidence that an exchange partner will not behave opportunistically, cognitive trust is based on accurate exchange of information among partners, affective trust implies identification with an exchange partner, wheras behavioural trust is reflected in a company's willingness to assume risk and establish partnership (Akrout \& Diallo, 2017). According to the aforementioned multistage model, trust in buyer-supplier relationships is a process which evolves through lifecycle stages, such as calculative, cognitive, affective and behavioural trust. Building of trustworthy relationships is regarded as an investment with a long-term payoff (Doney \& Cannon, 1997). Trust has been recognized as a key prerequisite for retaining customers and the development of long-term relationships with customers and a key determinant of customers' willingness to use organization's services more intensively and buy additional goods and services from the same provider (Aurier \& N'Goala, 2010). Trust in a buyer-supplier relationship increase the likelihood that a buyer will cooperate with the same supplier in the future (Doney \& Cannon, 1997). Trust is particularly valued in business relationships which imply that a company does not have control over its exchange partner, but it transfers valuable resources to the partner and the consequences of an exchange partner's actions can significantly affect company's performance. According to Acrout and Diallo (2017) trust is a key construct in $\mathrm{B} 2 \mathrm{~B}$ relationships, especially when few potential partners operate on the market and where switching costs are high, interdependence among companies is present and a buying process is long and complex. Trust is particularly relevant in buyer-seller relationships which imply the exchange of services, due to their intangibility, variability and difficulties in the assessments of service quality (Palmatier et al., 2006). Strongly related to trust is the construct of commitment.

\subsection{Relationship commitment}

Commitment is regarded as the basic requirement for successful buyersupplier relationships. According to Moorman et al. (1992; p.316) commitment 
Milošević I. et. al.: The determinants of cooperation in buyer-supplier relationships...

is "an enduring desire to maintain a valued relationship". Relationship commitment exists when an exchange partner considers a relationship as valuable enough to justify investing maximum efforts in order to maintain the relationship in the long term (Caceres \& Paparoidamis, 2007). Committed partners are likely to resolve potential disputes and less likely to break the relationship, even when more competitive offers are received. Commitment in buyer-supplier relationships leads to concerted efforts of exchange partners to meet the needs of end-customers more effectively, which result in profitability of working partners above the level that would be achieved by independent actions (Caceres \& Paparoidamis, 2007; Whipple et al., 2010).

In addition to Moorman et al.'s (1992) global conceptualization of commitment, which has been adopted in this study as well, recent research differentiates between affective, calculative and normative commitment (Cater \& Cater, 2010; Rafiq et al., 2013). Affective commitment is an intention to continue a relationship based on a company's identification with a supplier, their common values and similarity. Calculative commitment includes positive (value-based) commitment stemming from perceived benefits of the relationship and negative (locked-in) commitment stemming from high switching costs or lack of alternative suppliers, whereas normative commitment stems from a company's moral obligation to stay in the relationship.

\subsection{Relationship satisfaction}

In addition to trust and commitment, relationship satisfaction has been also recognized as an antecedent of cooperation, i.e. coordinated actions of exchange partners which are directed towards the achievement of mutual goals (Palmatier et al., 2006). Literature defines relationship satisfaction as "a positive emotional and rational state resulting from the assessment of the buyer's working relationship with the supplier" (Lages et al., 2008; p.688). It is a summary of a buyer's previous experience with the supplier which shapes buyer's expectations of relationship development. Previous studies make distinctions between transaction-specific and cumulative satisfaction, whereas transaction-specific satisfaction is an evaluation of a specific purchase encounter and cumulative satisfaction is an overall evaluation which is shaped by purchase and consumption experience gained over time (Lam et al., 2004; Lai \& Chen, 2010). As relationship satisfaction encompasses all facets of a company's relationship with its exchange partner, during the lifecycle of a relationship, it should be regarded as a cumulative satisfaction (AbdulMuhmin, 2005). Review of relationship marketing literature indicates that trust and communication among exchange partners have positive impact on relationship satisfaction (Whipple et al., 2010; Rafiq et al., 2013), which further contributes to the development of relationship commitment (Caceres \& 
Milošević l. et. al.: The determinants of cooperation in buyer-supplier relationships...

Paparoidamis, 2007; Aurier \& N'Goala, 2010). According to Abdul-Muhmin's (2005) study of relationships between manufacturing companies and their suppliers, relationship satisfaction is determined by both interpersonal factors, such as benevolence and credibity of a supplier, and instrumental factors, such as product quality, whereas interpersonal factors emerged as more significant drivers of relationship satisfaction. Instrumental factors, such as satisfaction with the components of a supplier's marketing mix, are important for the initiating of a relationship, whereas interpersonal factors, such as perceived benevolence and credibility of a supplier, contribute to the strengthening of a relationship. Recent empirical findings from the perspective of manufacturing companies as suppliers provide support for significant direct impact of logistics service quality provided by a manufacturer on its satisfaction with the relationship with its key account (Yu et al., 2017). Both relationship satisfaction and relationship commitment have been found to decrease buyer's propensity to terminate relationship with a supplier (AbdulMuhmin, 2005).

\subsection{Conceptual framework}

Sharing of information among partners in a buyer-supplier relationship assists in solving eventual disputes and alining expectations and perceptions and therefore fosters trust among partners (Whipple et al., 2010). In addition, communication among exchange partners leads to higher level of commitment to the relationship (Dowell et al., 2015).

The construct of trust is regarded as a cornerstone of strategic cooperation and a key determinant of relationship commitment (Anderson \& Narus, 1990; Morgan \& Hunt, 1994; Huang \& Wilkinson, 2013). Findings of Čater and Čater's (2010) study on a sample of manufacturing companies in Slovenia indicated significant impact of trust on commitment in buyer-supplier relationships. The antecedent role of trust to relationship commitment has been supported by a number of studies in the context of B2B markets (Moorman et al., 1992; Caceres \& Paparoidamis, 2007; Huang \& Wilkinson, 2013). According to Barry et al.'s (2008) cross-cultural investigation of buyersupplier relationship strength in the context of services, buyers' relationship commitment stems from the trustworthiness of suppliers, relational bonding and relationship satisfaction.

Prior empirical findings indicate significant role of trust and commitment for the establishment of cooperation among exchange partners (De Carvalho \& Sequeira, 2013; Huang \& Wilkinson, 2013). A meta analytical study of Palmatier et al. (2006) indicates that frequency and quality of communication among exchange partners adds to higher levels of trust, commitment and relationship satisfaction in buyer-seller relationships, which further contribute to cooperation among exchange partners (Palmatier et al., 2006). The 
Milošević l. et. al.: The determinants of cooperation in buyer-supplier relationships...

consequence of cooperation is value creation which surpasses individual achievements of each exchange partner. Cooperation in buyer-seller relationships evolves when exchange partners work on the improvement of joint performance and rather think in terms of "we" instead of "me" (Whipple et al., 2010). Buyer-supplier cooperation may result in a number of competitive advantages, such as lower transactional costs, reduced opportunism of exchange partners, quality improvement, increased flexibility, sales growth and profitability (Whipple et al., 2010).

The above discussion leads to the following hypotheses:

$\mathrm{H} 1$ : Communication in a buyer-supplier relationship has a significant positive influence on buyer's trust in the relationship;

H2: Communication in a buyer-supplier relationship has a significant positive influence on buyer's satisfaction with the relationship;

H3: Communication in a buyer-supplier relationship has a significant positive influence on relationship commitment;

$\mathrm{H} 4$ : Trust has a significant positive effect on relationship commitment;

H5: Trust has a significant positive effect on buyer's satisfaction with the relationship;

H6: Buyer's satisfaction with the relationship has a significant positive effect on relationship commitment;

$\mathrm{H} 7$ : Trust in the relationship significantly affects buyer-supplier cooperation;

H8: Satisfaction with the relationship significantly affects buyer-supplier cooperation;

H9: Relationship commitment has a significant positive influence on buyersupplier cooperation.

Conceptual model which integrates hypothesized relationships is presented in Figure 1.

Figure 1. Conceptual model of the development of buyer-supplier cooperation

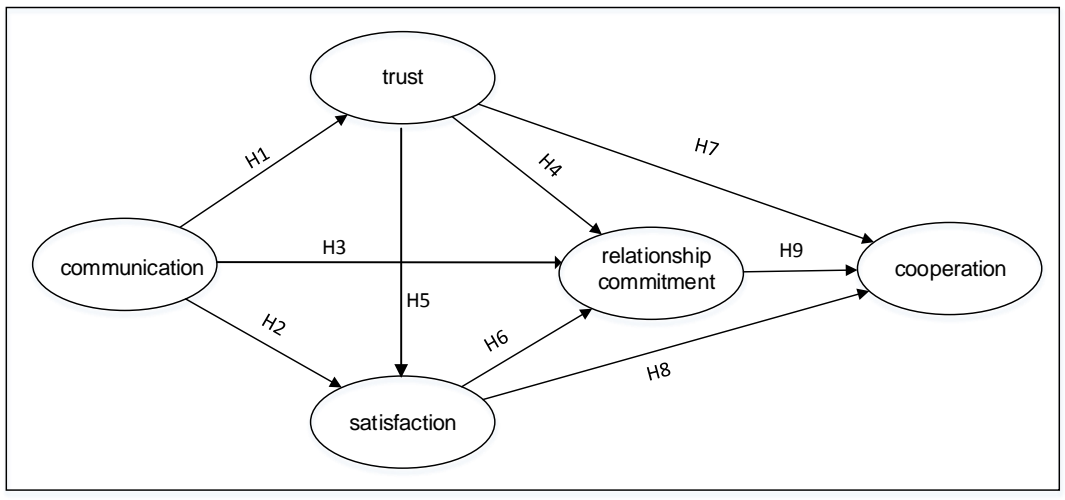

Source: authors' 
Milošević l. et. al.: The determinants of cooperation in buyer-supplier relationships...

\section{Research methodology}

The study has been conducted on a sample of ISO-certified companies. Companies' perspective as buyers in a supply chain relationship was the subject of examination. Data collection has been performed by means of personal and web-based interviewing. Data were gathered by means of selfadministered structured questionnaire and personnel in charge for procurement processes in certified companies participated in the study. Contact details of certified companies were provided by a certification body in Serbia. Respondents' task was to rate the main supplier of their company. The exclusion of incomplete questionnaires and questionnaires indicating that company's business processes are not governed by the standards yielded 186 responses which were entered into analysis, out of a total number of 300 distributed questionnaires. As the percentage of certified companies is very small $(2.11 \%$ of the total number of companies), data collection from this category of companies was not easy at all.

Questionnaire items were proposed on the basis of existing literature. Items were measured on a five-point Likert-type scale, ranging from 1-completely disagree to 5-completely agree. Communication was measured using four items adapted from Cannon and Perreault (1999) and Polo-Redondo and Cambra-Fierro (2008). Respondents were asked to indicate the extent to which their companies share information with suppliers, their expectations related to being informed by the supplier about important events and happenings which may affect their business, the extent of frequency and formality of communication in buyer-supplier relationships and timely receipt of information from the supplier. Trust was measured with four items, in accordance with the conceptualization of the construct proposed by Moormane et al. (1993) and Morgan and Hunt (1994). Respondents' task was to indicate their perceptions regarding supplier's care about their business, reliability, integrity and sincerity. Four items adapted from relationship marketing literature (Walter et al., 2003; Polo-Redondo \& Cambra-Fierro, 2008; Dowell et al., 2015) were used to measure relationship commitment. The scale captured respondents' perceptions of their company's willingness to invest time and resources into the relationship with the supplier, willingness to maintain the relationship, comply with the terms and conditions agreed with the supplier. Relationship satisfaction was measured with four items adapted from the literature (Walter et al., 2003; Polo-Redondo \& Cambra-Fierro, 2008). Respondets were asked to report to what extent their relationship with the supplier met their expectations, to compare relationship with the supplier to an ideal one, and to what extent they are satisfied with supplier's behaviour regarding keeping promises and to rate their relationship with the supplier. Items used to measure cooperation were derived from the measures proposed by Polo-Redondo and Cambra-Fierro (2008). Respondents were 
Milošević l. et. al.: The determinants of cooperation in buyer-supplier relationships...

asked to indicate the extent to which their company cooperates with the supplier, cooperation with the supplier in solving potential problems and the probability of engaging the same supplier when new business opportunites arise.

Hypothesized relationships were examined by means of structural equation modelling, adhering to Anderson and Gerbing's (1988) two-step procedure, which implies the examination of measurement model prior to the examination of structural relationships among the constructs. Maximum likelihood was applied as a method of parameter estimation. Data analyses were performed using LISREL v. 8.80 and SPSS v. 17.

\section{Results}

A confirmatory factor analysis was performed first to test the measurement model. Covariance matrix was used as an input to LISREL 8.80. Although measurement analysis yielded statistically significant and therefore unacceptable chi-square value $\left(x^{2}=320.34, d f=160, p<0.001\right)$, the ratio of chisquare value to degrees of freedom was lower than $3(x 2 / \mathrm{df}=2.002)$ and therefore suggested acceptable fit of the measurement model (Milosevic et al., 2015). Incremental fit indices being higher than the lower threshold of 0.90 $(\mathrm{CFI}=0.97, \mathrm{NFI}=0.94, \mathrm{NNFI}=0.96 ; \mathrm{RFI}=0.93)$ and absolute fit indices being lower than the recommended value of 0.08 (SRMR $=0.059, \mathrm{RMSEA}=0.074$ ) also supported good fit of the model to the data (Lin \& Wang, 2006).

Internal consistency of the constructs is indicated by Cronbach's alpha values being higher than the lower threshold of 0.60 . Although the indicators of good reliability are Cronbach's alpha values of 0.70 and higher, in exploratory research even lower threshold of 0.60 is deemed acceptable (Hair et al., 2010). Composite reliability values, as presented in Table 1, being higher than the lower threshold of 0.60 indicated that the measurement items consistently represented their respective latent constructs and provided evidence in support of convergent validity. All item loadings on their respective constructs were statistically significant and all but one were higher than the lower threshold of 0.50 , indicating convergent validity of the constructs (Hair et al., 2010).

Structural analysis yielded statistically significant and therefore unacceptable chi-square value $(x 2=234.13, \mathrm{df}=161, \mathrm{p}<0.001)$. However, normed chi-square and other fit indices were within the acceptable range and indicated good fit of the model to the data $(\mathrm{X} 2 / \mathrm{df}=1.45, \mathrm{CFI}=0.99, \mathrm{NFI}=0.96, \mathrm{NNFI}=0.98, \mathrm{RFI}=0.95$, RMSEA $=0.050$, SRMR $=0.063$ ). Therefore, in the following stage path coefficients of proposed structural model were examined. Out of nine 
Milošević l. et. al.: The determinants of cooperation in buyer-supplier relationships...

proposed hypotheses, structural analysis provided support for five structural relations, as presented in Table 2 .

Table 1. Measurement model properties

\begin{tabular}{|l|l|l|l|l|}
\hline Constructs & $\begin{array}{l}\text { Standardized } \\
\text { factor loadings }\end{array}$ & t-values & $\begin{array}{l}\text { Composite } \\
\text { reliability }\end{array}$ & $\begin{array}{l}\text { Cronbach's } \\
\text { alpha }\end{array}$ \\
\hline Communication & & & 0.788 & 0.786 \\
\hline INF1 & 0.75 & 11.14 & & \\
\hline INF2 & 0.64 & 9.00 & & \\
\hline INF3 & 0.62 & 8.74 & & \\
\hline INF4 & 0.76 & 11.27 & & \\
\hline Trust & & & 0.832 & 0.828 \\
\hline T1 & 0.66 & 9.46 & & \\
\hline T2 & 0.75 & 11.27 & & \\
\hline T3 & 0.79 & 12.12 & & \\
\hline T4 & 0.78 & 11.91 & & \\
\hline Satisfaction & & & 0.845 & 0.840 \\
\hline S1 & 0.75 & 11.42 & & \\
\hline S2 & 0.75 & 11.34 & & \\
\hline S3 & 0.79 & 12.26 & & \\
\hline S4 & 0.75 & 11.34 & & \\
\hline Commitment & & & 0.846 & 0.851 \\
\hline C1 & 0.77 & 11.83 & & \\
\hline C2 & 0.85 & 13.70 & & \\
\hline C3 & 0.78 & 12.19 & & \\
\hline C4 & 0.66 & 9.59 & & \\
\hline Cooperation & & & 0.653 & \\
\hline COO1 & 0.61 & 8.38 & & \\
\hline COO2 & 0.69 & 9.67 & & \\
\hline COO3 & 0.55 & 7.36 & & \\
\hline COO4 & 0.40 & 5.18 & & \\
\hline
\end{tabular}

Source: authors'

Communication emerged as a significant determinant of trust $\left(\mathrm{Y}_{21}=0.77\right.$, $\mathrm{t}=6.31$ ), providing support for hypothesis $\mathrm{H} 1$. Contrary to what was expected, the direct impacts of communication on relationship satisfaction $\left(\gamma_{31}=0.25\right.$, $\mathrm{t}=1.60)$ and relationship commitment $\left(\mathrm{\gamma}_{41}=0.25, \mathrm{t}=1.69\right)$ were not significant. Therefore, hypotheses $\mathrm{H} 2$ and $\mathrm{H} 3$ were not supported. The direct impact of trust on relationship commitment was not significant $\left(\beta_{42}=-0.11, t=-0.52\right)$. Therefore, support was not provided for hypothesis $\mathrm{H} 4$. Trust emerged as a significant determinant of relationship satisfaction $\left(\beta_{32}=0.62\right.$, $\left.t=3.62\right)$, providing support for hypothesis $\mathrm{H} 5$. As expected, relationship satisfaction had a strong positive influence on relationship commitment $\left(\beta_{43}=0.68, t=3.64\right)$, providing support for hypothesis $\mathrm{H} 6$. The effect of trust on cooperation was significant 
Milošević l. et. al.: The determinants of cooperation in buyer-supplier relationships...

$\left(\beta_{52}=0.74, t=3\right)$. Thus, hypothesis $\mathrm{H} 7$ was supported. Contrary to what was expected, the direct impact of relationship satisfaction on cooperation was not significant $\left(\beta_{53}=-0.29, t=-1.17\right)$. Therefore, hypothesis $\mathrm{H} 8$ was not supported. The direct impact of relationship commitment on cooperation was significant $\left(\beta_{54}=0.50, t=3.62\right)$, providing support for hypothesis H9. Altogether, trust, satisfaction and relationship commitment accounted for $78 \%$ of the variance in cooperation, which indicates good explanatory power of the model.

Table 2. Results of hypothesis testing

\begin{tabular}{|c|c|c|c|}
\hline Hypotheses & $\begin{array}{l}\text { Standardized } \\
\text { estimates }\end{array}$ & t-value & Results \\
\hline $\begin{array}{l}\mathrm{H} 1: \\
\text { trust }\end{array}$ & 0.77 & 6.31 & Supported \\
\hline $\begin{array}{l}\text { H2: communication } \rightarrow \\
\text { satisfaction }\end{array}$ & 0.25 & 1.60 & Not supported \\
\hline $\begin{array}{l}\text { H3: communication } \rightarrow \\
\text { commitment }\end{array}$ & 0.25 & 1.69 & Not supported \\
\hline H4: trust $\rightarrow$ commitment & -0.11 & -0.52 & Not supported \\
\hline H5: trust $\rightarrow$ satisfaction & 0.62 & 3.62 & Supported \\
\hline $\begin{array}{l}\text { H6: satisfaction } \rightarrow \\
\text { commitment }\end{array}$ & 0.68 & 3.64 & Supported \\
\hline H7: trust $\rightarrow$ cooperation & 0.74 & 3 & Supported \\
\hline $\begin{array}{l}\text { H8: satisfaction } \rightarrow \\
\text { cooperation }\end{array}$ & -0.29 & -1.17 & Not supported \\
\hline $\begin{array}{l}\text { H9: commitment } \rightarrow \\
\text { cooperation }\end{array}$ & 0.50 & 3.62 & Supported \\
\hline
\end{tabular}

Source: authors'

\section{Discussion}

The aim of this research was to propose and empirically examine the model explaining the development of buyer-supplier cooperation, from the perspective of certified companies operating in Serbia, which figure as buyers in the relationship. Results of the study indicate significant direct impact of communication on the promotion of trust among exchange partners and as such are largely in compliance with previous research (Morgan \& Hunt, 1994; Akrout \& Diallo, 2017). Contrary to what was expected according to some previous research (Whipple et al., 2010), exchange of information among partners in a buyer-supplier relationship, from the perspective of buyers, did not result directly in the enhancement of relationship satisfaction and commitment to the relationship. However, communication among exchange 
Milošević I. et. al.: The determinants of cooperation in buyer-supplier relationships...

partners indirectly contributes to buyer's satisfaction with the relationship, whereas this impact is fully mediated via buyer's perceptions of trust in the exchange partner. Unlike previous studies indicating direct influence of trust on relationship commitment (Aurier \& N'Goala, 2010; Čater \& Čater, 2010; Dowell et al., 2015), findings of this research indicate that buyer's perceptions of an exchange partner's trustworthiness contribute to buyer's perception of a satisfactory working relationship with the supplier, which further contributes to buyer's desire to continue satisfactory relationship with the supplier. Although the impact of trust on commitment is mediated by relationship satisfaction, both trust and commitment emerged as direct antecedents to cooperation, providing support for Morgan and Hunt's (1994; p.20) notion that "successful relationship marketing requires relationship commitment and trust". The direct impact of both trust and relationship commitment on the promotion of cooperation in a buyer-supplier relationship, whereas trust emerged as a stronger antecedent to cooperation than relationship commitment, is in line with Palmatier et al.'s (2006) findings stemming from a meta-analytical study of relationship marketing research.

Results of this study bear both managerial and theoretical implications. Findings of this study contribute to relationship marketing literature by providing insights into the determinants of cooperation, as a relationship marketing outcome, in buyer-supplier relationships from the perspective of certified companies in Serbia. This study's findings can also assist suppliers' management in decision making. Results of the study indicate that intensified communication among buyers and suppliers promote trust among exchange partners. As the probability of being engaged as a supplier by the certified company-buyer rises with buyer's perceptions of the supplier as a reliable and trustworthy parner, managers of supplier companies are advised to take more active role in the exchange of information with buyers in order to gain deeper knowledge of buyer's needs, contribute to realistic expectations of a buyer and deliver goods and services required by the buyer in a manner which not only meets, but exceeds buyer's expectations. Buyer's confidence in a supplier's reliability and integrity is expected to directly lead to higher level of cooperation with the supplier and indirectly improve cooperation by enhancing buyer's perceptions of relationship satisfaction and a desire to sustain a relationship with valuable exchange partner.

The present study has some limitations and the caution is therefore advised with regard to the generalisability of research findings. As this study employed cross-sectional research design, inferences regarding the extent and the direction of causality among the constructs should be taken with caution. Therefore, future researchers are advised to apply a longitudinal methodology. A limitation of this study is that perceptions of cooperation were rated only from the perspective of buyers. As relationships require two sides, future studies would benefit from including the perspective of supplier 
Milošević l. et. al.: The determinants of cooperation in buyer-supplier relationships...

companies. Another limitation of this research is that trust and commitment have been measured as global and unidimensional constructs. Deeper insights of the relationships between these constructs and their relative impact on the improvement of cooperation could be gained taking into account their multidimensional structure, which should be the focus of future research. However, further research could extend present findings by examining the role of trust, relationship satisfaction and commitment on the development of loyalty in buyer-supplier relationships, in line with previous research in B2C setting indicating significant impact of trust and satisfaction on customer loyalty (Rajic et al., 2016). Managerially significant insights could be obtained by examining the impact of relationship quality constructs on attitudinal and behavioural loyalty. The impact of quality of services provided by suppliers and perceived value of supplier's offer on relationship quality constructs and their influence on buyer's behavioural intentions would be an avenue worthy of future examination. Future studies should also take into account the dynamic nature of trust and commitment. Relationships among the constructs and their contribution to relationship marketing outcomes should be examined in different phases of the relationship lifecycle.

\section{Conclusions}

This study is an attempt to investigate the determinants of cooperation in buyer-supplier relationships from the perspective of certified buyers. To achieve this aim this study integrates the constructs of cooperation, trust, relationship satisfaction and commitment to the relationship in a model of buyer-supplier cooperation. According to this study's findings intensified communication among exchange partners promotes trust in buyer-supplier relationships which contributes to buyer's perceptions of relationship satisfaction. Both trust and commitment directly contribute to higher levels of cooperation in buyer-supplier relationships. Buyer's belief that the supplier will act having buyer's best interest at heart contributes to buyer's satisfaction with the relationship, which further strengthens buyer's desire to maintain the relationship with the supplier and contributes to the promotion of cooperation in buyer-supplier relationship. This study is the first attempt to examine factors which promote cooperation in buyer-supplier relationships from the perspective of certified buyers. Providing evidence of significant influence of both trust and commitment, measured as global constructs, on the development of cooperation in buyer-supplier relationships of certified companies, this study contributes to the growing body of knowledge on B2B relationships. 
Milošević l. et. al.: The determinants of cooperation in buyer-supplier relationships...

\section{References}

Abdul-Muhmin, A. G. (2005). Instrumental and interpersonal determinants of relationship satisfaction and commitment in industrial markets. Journal of Business Research, 58, 619-628.

Akrout, H., \& Diallo, M. F. (2017). Fundamental transformations of trust and its drivers: A multi-stage approach of business-to-business relationships. Industrial Marketing Management, 66, 159-171.

Alic, M. (2014). Impact of ISO 9001 certification cancellation on business performance: a case study in Slovenian organisations. Total Quality Management, 25(7), 790 -811. http://dx.doi.org/10.1080/14783363.2014.906107

Anderson, J. C., \& Narus, J. A. (1990). A Model of Distributor Firm and Manufacturer Firm Working Partnerships. Journal of Marketing, 54, $42-58$.

Aurier, P., \& N'Goala, G. (2010). The differing and mediating roles of trust and relationship commitment in service relationship maintenance and development. Journal of the Academy of Marketing Science, 38, 303-325.

Barry, J. M., Dion, P., \& Johnson, W. (2008). A cross-cultural examination of relationship strength in B2B services. Journal of Services Marketing, 22(2), 114135.

Caceres, R. C., \& Paparoidamis, N. G. (2007). Service quality, relationship satisfaction, trust, commitment and business-to-business loyalty. European Journal of Marketing, 41(7/8), 836-867.

Cannon, J., \& Perrault, W. (1999). Buyer-seller relationships in business markets. Journal of Marketing Research, 36, 439-460.

Cater, T., \& Čater, B. (2010). Product and relationship quality influence on customer commitment and loyalty in B2B manufacturing relationships. Industrial Marketing Management, 39, 1321-1333.

de Carvalho, J. C., \& Sequeira, L. (2013). Buyer-seller conflict and cooperation in marketing channels: port wine distribution. International Journal of Wine Research, 5, 9-21.

Doney, P. M., \& Cannon, J. P. (1997). An Examination of the Nature of Trust in BuyerSeller Relationship. Journal of Marketing, 61, 35-51.

Dowell, D., Morrison, M., \& Heffernan, T. (2015). The changing importance of affective trust and cognitive trust across the relationship lifecycle: A study of business-tobusiness relationships. Industrial Marketing Management, 44, 119-130.

Fleming, D., Lynch, P., \& Kelliher, F. (2016). The process of evaluating business to business relationships facing dissolution: An SME owner manager perspective. Industrial Marketing Management, 58, 83-93.

Hair, J.F., Black, W.C., Babin, B.J., \& Anderson, R.E. (2010). Multivariate Data Analysis: A Global Perspective, Upper Saddle River. New Jersey: Pearson Prentice Hall, (7th ed.).

Huang, Y., \& Wilkinson, I. F. (2013). The dynamics and evolution of trust in business relationships. Industrial Marketing Management, 42, 455-465.

Kauffman, R. J., \& Tsai, J. Y. (2010). With or without you: The countervailing forces and effects of process standardization. Electronic Commerce Research and Applications 9, 305-322. 
Milošević l. et. al.: The determinants of cooperation in buyer-supplier relationships...

Lages. L. F., Lancastre, A., \& Lages, C. (2008). The B2B-RELPERF scale and scorecard: Bringing relationship marketing theory into business-to-business practice. Industrial Marketing Management, 37, 686-697.

Lai, W.-T., \& Chen, C.-F. (2010). Behavioral intentions of public transit passengersThe roles of service quality, perceived value, satisfaction and involvement. Transport Policy, 18(2), 318-325.

Lam, S. Y., Shankar, V., Erramilli, K. M., \& Murthy, B. (2004). Customer Value, Satisfaction, Loyalty, and Switching Costs: An Illustration From a Business-toBusiness Service Context. Journal of the Academy of Marketiag Science, 32(3), 293-311.

Lin, H.-H., \& Wang, Y.-S. (2006). An examination of the determinants of customer loyalty in mobile commerce contexts. Information \& Management, 43, 271-282.

Miloševic, I., Zivkovic, D., Manasijevic, D., \& Nikolic, D. (2015). The effects of the intended behavior of students in the use of M-learning. Computers in Human Behavior, 51, 207-215.

Mohr, J., Fischer, R., \& Nevin, J. (1996). Collaborative communication in interfirm relationships: Moderating effects of integration and control. Journal of Marketing, 60, 103-115.

Moorman, C., Zaltman, G., \& Deshpande, R. (1992). Relationships Between Providers and Users of Market Research: The Dynamics of Trust Within and Between Organizations. Journal of Marketing Research, 29, 314-328.

Moorman, C., Deshpande, R., \& Zaltman, G. (1993). Factors Affecting Trust in Market Research Relationships. Journal of Marketing, 57, 81-101.

Morgan, R. M., \& Hunt, S. D. (1994). The Commitment-Trust Theory of Relationship Marketing. Journal of Marketing, 58, 20-38.

Palmatier, R. W., Dant, R. P., Grewal, D., \& Evans, K. R. (2006). Factors Influencing the Effectiveness of Relationship Marketing: A Meta-Analysis. Journal of Marketing, 70, 136-153.

Polo-Redondo, Y., \& Cambra-Fierro, J. (2008). Influence of the standardization of a firm's productive process on the long-term orientation of its supply relationships: An empirical study. Industrial Marketing Management, 37, 407-420.

Rafiq, M., Fulford, H., \& Lu, X. (2013). Building customer loyalty in online retailing: The role of relationship quality. Journal of Marketing Management, 29(3-4), 494517.

Rajic. T., Nikolic, I., \& Milosevic, I. (2016). The Antecedents of SMEs' Customer Loyalty: Examining the role of Service Quality, Satisfaction and Trust. Industry, 44(3), 97-114.

Rubio-Andrada, L., Alonso-Almeida, M. D. M., \& Rodrıguez-Anton, J. M. (2011). Motivations and impacts in the firm and stakeholders of quality certification: Evidence from small- and medium-sized service enterprises. Total Quality Management, 22(8), 833-852.

Swann, P. G. M. (2000). The Economics Of Standardization, Final report for standards and technical regulations directorate. London: Department of trade and industry, http://www.dti.gov.uk/files/file11312.pdf

Trajković, A., \& Milošević, I. (2018). Model to Determine the Economic and Other Effects of Standardization - Case Study in Serbia. Total Quality Management \& Business Excellence, 29(5-6), 673-685. https://doi.org/10.1080/14783363.2016.1225496. 
Milošević l. et. al.: The determinants of cooperation in buyer-supplier relationships...

Walter, A., Müller, T., Helfert, G., \& Ritter, H. (2003). Functions of industrial supplier relationships and their impact on relationship quality. Industrial Marketing Management, 32, 159-169.

Whipple. J. M., Lynch, D. F., \& Nyaga, G. N. (2010). A buyer's perspective on collaborative versus transactional relationships. Industrial Marketing Management, 39, 507-518.

Wu, S.-I., \& Jang, J.-Y. (2013). The performance of ISO certification based on consumer perspective: A case study of a travel agency. Total Quality Management, 24(4), 496 -518. http://dx.doi.org/10.1080/14783363.2011.560704

Wu, S.-I., \& Jang, J.-Y. (2014). The impact of ISO certification on consumers' purchase intention. Total Quality Management, 25(4), 412-426. http://dx.doi.org/10.1080/14783363.2013.776770

Yu, K., Cadeaux, J., \& Song, H. (2017). Flexibility and quality in logistics and relationships. Industrial Marketing Management, 62, 211-225. 